\title{
ACys amyloidosis
}

INSERM

\section{Source}

INSERM. (1999). Orphanet: an online rare disease and orphan drug data base. ACyS amyloidosis. ORPHA:100008

Hereditary cerebral hemorrhage with amyloidosis (HCHWA), Icelandic type is a form of HCHWA (see this term) characterized by an age of onset of 20-30 years, systemic amyloidosis and recurrent lobar intracerebral hemorrhages. 